\title{
Pinhole-Free PbS Thin Films Obtained by Chemical Bath Deposition Method
}

\section{Kimyasal Banyo Biriktirme Yöntemiyle Elde Edilen İğne Deliksiz PbS İnce Filmler}

\author{
Hale Y1ldizay ${ }^{1 *}$ \\ Geliş / Received: 16/09/2021 \\ Revize / Revised: 02/11/2021 \\ Kabul / Accepted: 09/11/2021

\begin{abstract}
In this study, the (Lead Sulfide) PbS thin films with one, two, and three layers were fabricated by employing the chemical bath deposition method. Layer by layer production of $\mathrm{PbS}$ thin films was realized for the first time as seen in the literature review. For investigating the crystal structures, the X-ray diffraction (XRD) analysis was used. The structural analyses indicated that the crystallite size was decreased from about $40 \mathrm{~nm}$ to $8-10 \mathrm{~nm}$ depending on the number of layers. The surface micrographs of the films were obtained using scanning electron microscopy (SEM). When the PbS film was obtained in one layer, some cracks, pinholes, and voids were observed on the sample surface. However, no cracks, voids, or pinhole formation were found on the film surface when the films were coated in two and three layers.
\end{abstract}

Keywords- PbS, Characterization, Materials, Thin Film, CBD

$\overline{\mathbf{o z}}$

Bu çalışmada, kimyasal banyo biriktirme yöntemi kullanılarak tek, iki ve üç katmanlı (Kurşun Sülfür) PbS ince filmler üretilmiştir. Literatür taramasında görüldüğü gibi, $\mathrm{PbS}$ ince filmlerin katman katman üretimi ilk kez gerçekleştirilmiştir. Kristal yapılarını araştırmak için X-1şını difraktometre (XRD) analizi kullanıldı. Yapısal analizler kristalit boyutunun tabaka sayısına bağlı olarak yaklaşık $40 \mathrm{~nm}$ 'den 8-10 nm'ye düştüğünü göstermiştir. Filmlerin yüzey görüntüleri taramalı elektron mikroskobu (SEM) cihazı ile incelenmiştir. PbS filmi tek kat olarak elde edildiğinde numune yüzeyinde bazı çatlaklar, iğne delikleri ve boşluklar gözlenmiştir. Ancak filmler iki ve üç kat kaplandığında film yüzeyinde herhangi bir çatlak, boşluk veya iğne deliği oluşumu görülmedi.

Anahtar Kelimeler- PbS, Karakterizasyon, Malzeme, İnce Film, KBB

1*Sorumlu yazar iletişim: hale.yildizay@dpu.edu.tr (https://orcid.org/0000-0002-3896-9912)

El Sanatları Bölümü, Kütahya Güzel Sanatlar Meslek Yüksek Okulu, Kütahya Dumlupınar Üniversitesi, Kütahya, Türkiye 


\section{INTRODUCTION}

Lead sulfide $(\mathrm{PbS})$ is a very useful semiconductor material for various technological applications including absorber layers in thin-film solar cells [1,2], heterojunction photo voltaic cells [3,4], thermoelectric devices [5,6], infrared radiation detectors, [7,8] and chemical sensors [9]. Among the IV-VI semiconductors, $\mathrm{PbS}$ is an important direct narrow-gap semi-conductor material with a band gap energy of $0.4 \mathrm{eV}$ and it has a cubic lattice with a unit cell face centre cube[10]. $\mathrm{PbS}$ thin films have been deposited by several methods, such as thermal evaporation [11], galvanic method [12], electro deposition [13], pulsed laser deposition [14], spray pyrolysis [15], successive ionic layer adsorption and reaction (SILAR) [16-18], atomic layer deposition [19], sol-gel [20], chemical vapour deposition (CVD), [21] and chemical bath deposition (CBD) [22].The chemical bath deposition technique is quite simple compared to other techniques. It can be applied at low temperatures. It has a low process cost, and it can be easily applied to large surfaces [23]. The $\mathrm{PbS}$ precipitation process is as follows [24]:

$$
\begin{aligned}
& \mathrm{Pb}\left(\mathrm{NO}_{3}\right)_{2}+2 \mathrm{NaOH} \rightarrow \mathrm{Pb}(\mathrm{OH})_{2}+2 \mathrm{NaNO}_{3} \\
& (\mathrm{OH})_{2}+2 \mathrm{NaOH} \rightarrow \mathrm{Na}_{2}\left[\mathrm{~Pb}(\mathrm{OH})_{4}\right] \\
& {\left[(\mathrm{OH})_{4}\right]^{2-} \rightarrow \mathrm{Pb}^{2+}+4 \mathrm{OH}^{-}}
\end{aligned}
$$

Furthermore, the hydrolysis of thiourea (TU) $\left(\mathrm{NH}_{2}\right)_{2}$, in the solution releases $\mathrm{S}^{2-}$ ions as below:

$$
\begin{aligned}
& \left(\mathrm{NH}_{2}\right)_{2}+\mathrm{OH}^{-} \rightarrow \mathrm{CH}_{2} \mathrm{~N}_{2}+\mathrm{H}_{2} \mathrm{O}+\mathrm{HS}^{-} \\
& \mathrm{HS}^{-}+\mathrm{OH}^{-} \rightarrow \mathrm{H}_{2} \mathrm{O}+\mathrm{S}^{2-}
\end{aligned}
$$

When the $\mathrm{Pb}^{2+}$ and $\mathrm{S}^{2-}$ ions exceed the solubility limit in solution, the insoluble solid $\mathrm{PbS}$ precipitate as below:

$$
P b^{2+}+S^{2-} \rightarrow P b S
$$

According to the literature, when the $\mathrm{PbS}$ was obtained by chemical bath deposition, there occurred an important problem, such as cracks and pinholes [25,26]. These problems were eliminated in this study, in which the $\mathrm{PbS}$ films were produce done, two, and three times in arow. It was discovered that when the film was produced as two layers, the film surface was very compact and smooth.

\section{EXPERIMENTAL DETAILS}

Polycrystalline $\mathrm{PbS}$ thin films were produced by the chemical bath deposition (CBD) method onto glass substrates. In the experiment, thin films of $\mathrm{PbS}$ were obtained as one, two, and three layers. Before the depositions, the glass substrate surface and the bath container were washed with $10 \% \mathrm{HCl}$ acid in order to remove the impurities and residuals. After that, they were rinsed with deionized water. Referring to the literature [27]; $0.0085 \mathrm{M} \mathrm{Pb}$ $\left(\mathrm{NO}_{3}\right)_{2}$ and $0.1460 \mathrm{M} \mathrm{NaOH}$ were put in in $100 \mathrm{ml}$ deionized water, after then $0.510 \mathrm{M} \mathrm{SC}\left(\mathrm{NH}_{2}\right)_{2}$ thiourea added into the solution and mixed at $20^{\circ} \mathrm{C}$. The $\mathrm{pH}$ of the final solutions was measured as 11.5. The chemical reaction of the solution started in a short time, in about 30 seconds. The depositions were ended after 40 minutes. After precipitation, the samples were rinsed with deionized water.

The crystal structure of the $\mathrm{PbS}$ films was investigated by employing an $\mathrm{X}$-ray diffractometer, which is a PANALYTICAL-EMPYREAN X-ray diffractometer, for $2 \theta$ in range $20^{\circ}-70^{\circ}$. As a radiation source, we used Cu$\mathrm{K} \alpha$ radiation with a scan rate of $2 \% \mathrm{~min}$. The surface morphologies of the samples were analyzed by a Zeiss Supra 40VP SEM.

\section{RESULTS}

\section{A. Structural analysis}

$\mathrm{XRD}$ analysis was carried out on $\mathrm{PbS}$ films and typical diffraction patterns of $\mathrm{PbS}$ thin films prepared by chemical bath deposition technique on glass substrates were analyzed with different thickness values. The XRD patterns are presented in Figure 1. 


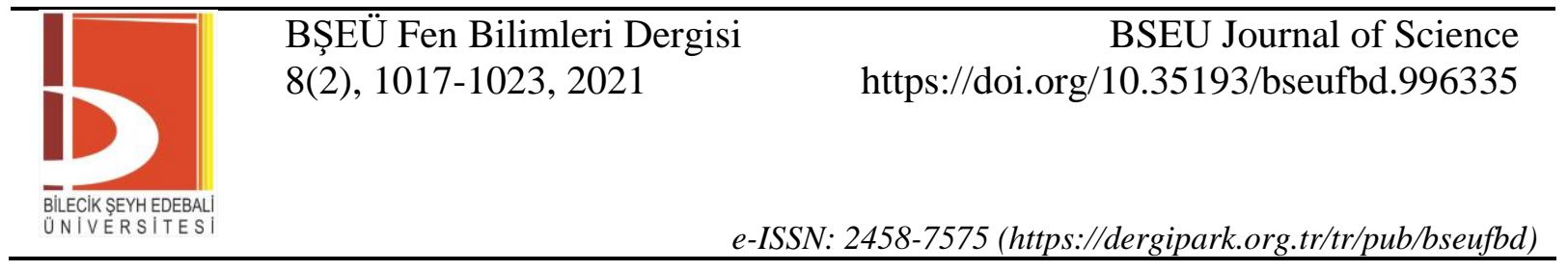

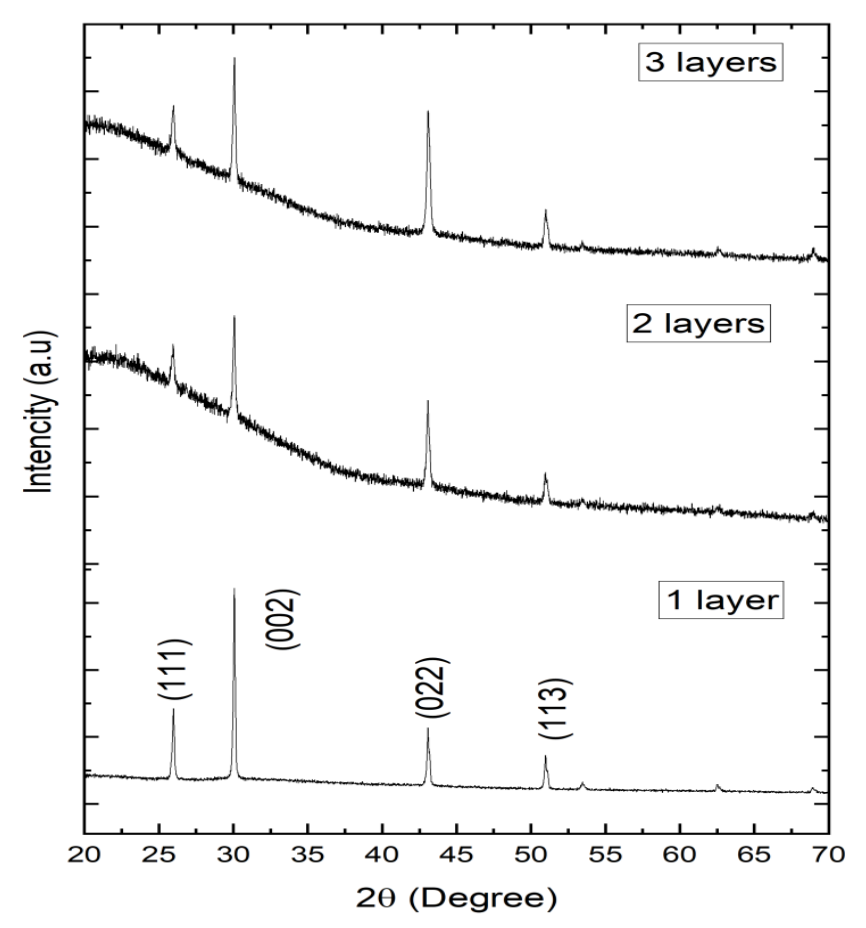

Figure 1. XRD Samples of the PbS films

The film thicknesses were calculated by the well-known gravimetric method. The film thicknesses were calculated as $620 \mathrm{~nm}, 950 \mathrm{~nm}$, and $1200 \mathrm{~nm}$ for one layer, two layers, and three layers, respectively.

The XRD schema is presented in Figure1. According to Figure1, the good crystallization is seen in the one-layer film. Two and three-layers film patterns showed relatively low crystallization. All peaks were related to the galena type cubic crystals according to the 98-060-0243 ASTM card no.

For calculating crystallite, the Debye-Scherer equation which is given in Equation (4) was used;

$$
\mathrm{cs}=\frac{0.089 * 180 * \lambda}{314 * \beta * \cos \theta_{C}} \mathrm{~nm}
$$

where $\beta$ is full width half maximum (FWHM), $\lambda$ is the wavelength of X-ray radiation (1.54056 $\AA$ ) and $2 \theta \mathrm{C}$ is the peak centre (28).

Table 1 presents the crystallite sizes of the samples. According to Table.1, the amazing results are noticed. When the thin films were produced as two and three layers, the crystallite sizes decreased about 5 times. Quantization effects are observed when the crystallite size of a semiconductor is near to or less than the bulk Bohr exciton radius [29,30]. Generally, when the crystallite size of $\mathrm{PbS}$ quantum dots decreases to $5-18 \mathrm{~nm}$, it is seen [31].

Table 1. The thicknesses and crystallite sizes of the $\mathrm{PbS}$ films

\begin{tabular}{ccc}
\hline Experimental & Thickness & Average crystallite size \\
\hline One Layer & $620 \mathrm{~nm}$ & $40.99 \mathrm{~nm}$ \\
Two Layers & $950 \mathrm{~nm}$ & $8.15 \mathrm{~nm}$ \\
Three Layers & $1200 \mathrm{~nm}$ & $10.20 \mathrm{~nm}$ \\
\hline
\end{tabular}

\section{B. SEM images of the PbS films}

The 10000 times magnified surface images are given in Figure 2. There can be seen plenty of cracks and pinholes on the surface of the one-layer PbS film. However, when the films were produced as two or three layers, the surface became compact and smooth. 


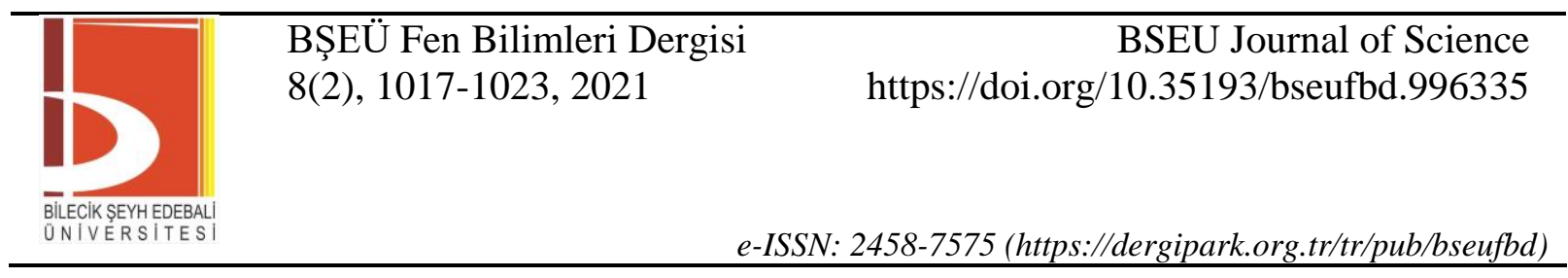

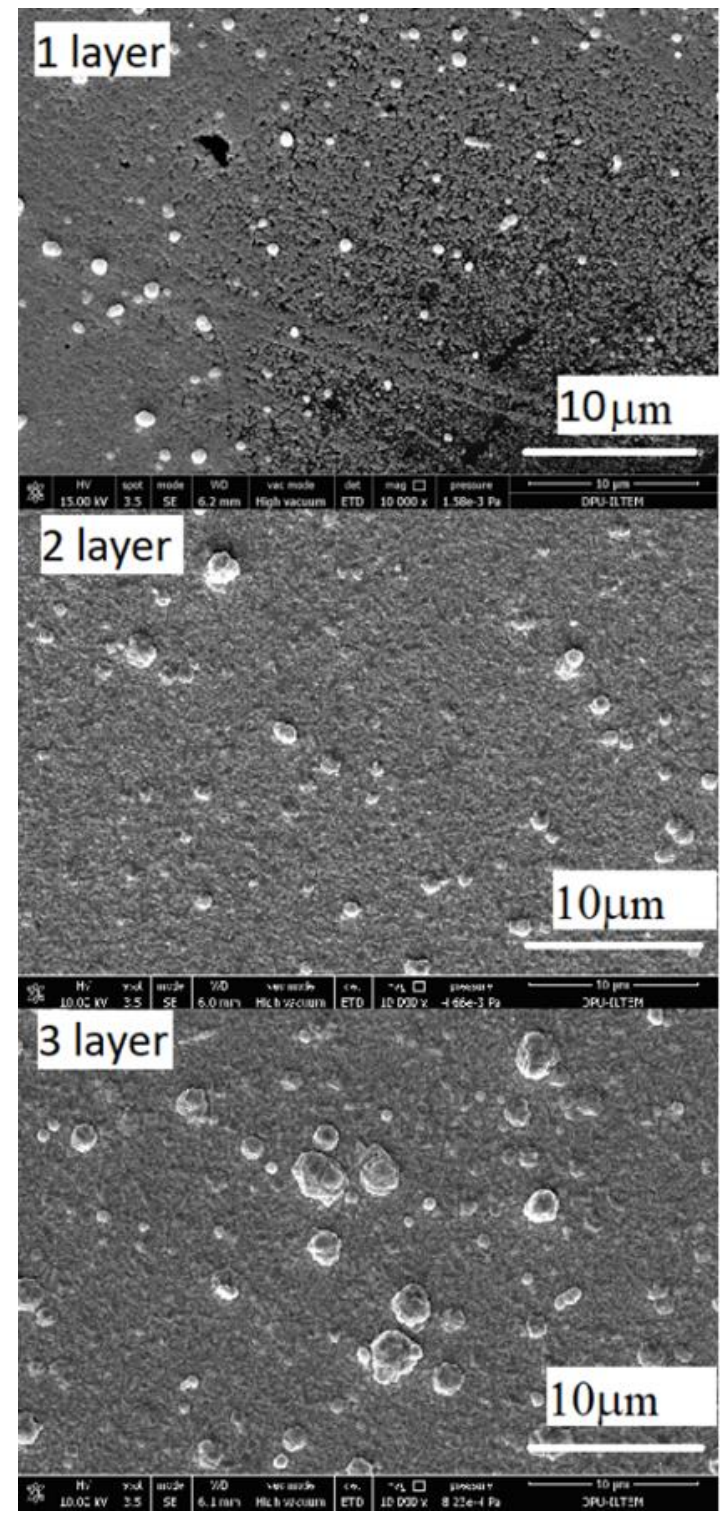

Figure 2. 10000 times magnified surface images of PbS films

In Figure 3, the surface images magnified 40000 times are given. According to these images, when the film was obtained as one layer, there were voids on the surface. On the other hand, when the films were obtained as two and three layers, the surfaces were quite compact and pinhole-free. 


\begin{tabular}{|c|c|c|}
\hline & $\begin{array}{l}\text { BŞEÜ Fen Bilimleri Dergisi } \\
8(2), 1017-1023,2021\end{array}$ & $\begin{array}{r}\text { BSEU Journal of Science } \\
\text { https://doi.org/10.35193/bseufbd.996335 }\end{array}$ \\
\hline & & 2458-7575 (https://dergipark.org.tr/tr/pub/bseufbd) \\
\hline
\end{tabular}

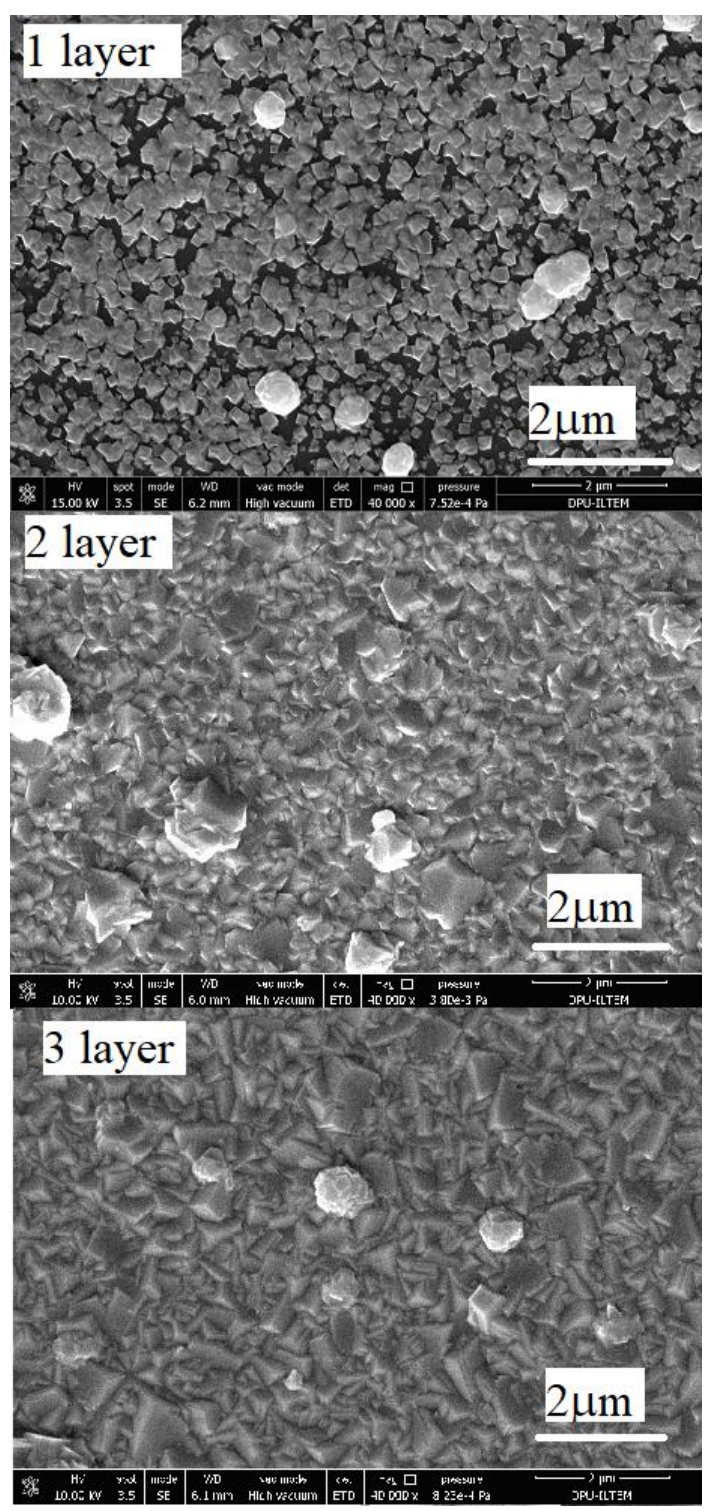

Figure 3. 40000 times magnified surface images of PbS films

\section{The visual properties of the PbS films}

The visual photos of the PbS thin films are given in Figure 4. According to the photos, the film obtained as one layer is relatively dark. On the other hand, the other samples are relatively weak. It was concluded that the differences in the colour could be due to crystallite sizes. 


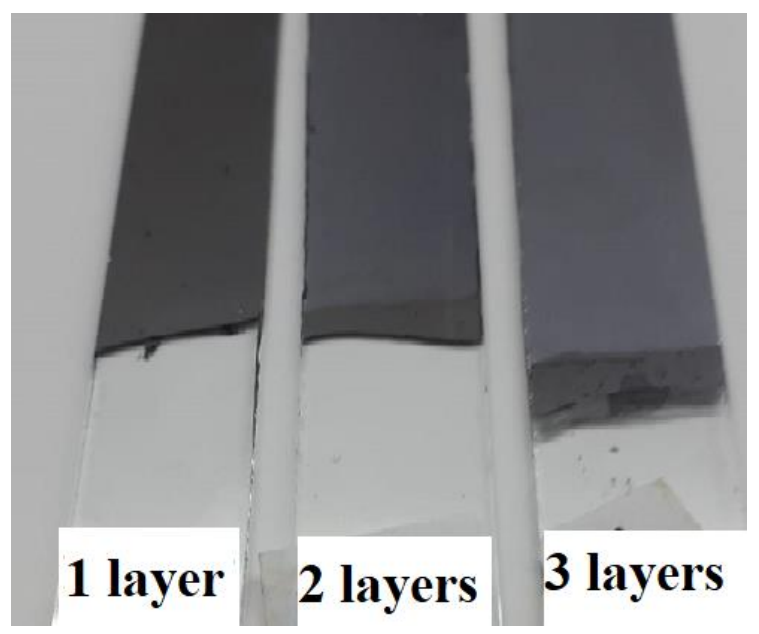

Figure 4. The surface photographs of the PbS films

\section{IV.DISCUSSION}

In this study, thin films of PbS were grown on glass substrates by using the CBD method. The PbS films were deposited as one, two, and three layers. The two and three layers of PbS films were obtained for the first time. The structural analysis was realized by using XRD pattern. All films were formed in galena type cubic structure. According to the patterns, the crystallite size was decreased from $40 \mathrm{~nm}$ to $8-10 \mathrm{~nm}$. The morphologic characteristics were investigated by SEM images. According to the both 10000-times and 40000-times magnified SEM images, when film was obtained one layer, there were plenty of cracks and voids on surface. The problem of cracks and holes was solved by producing films in two and three layers on top of each other.

\section{REFERENCES}

[1] Saikia, D., \& Phukan, P. (2014). Fabrication and evaluation of CdS/PbS thin film solar cell by chemical bath deposition technique. Thin Solid Films 562, 239-243.

[2] Mohamed, H.A. (2014). Theoretical study of the efficiency of CdS/PbS thin film solar cells. Sol. Energy 108, 360-369.

[3] Xing, M., Zhang, Y., Shen, Q., \& Wang, R. (2020). Temperature dependent photovoltaic performance of $\mathrm{TiO} 2 / \mathrm{PbS}$ heterojunction quantum dot solar cells. Sol. Energy 195, 1-5.

[4] Yao, X., Song, Z., Mi, L., Li, G., Wang, X., Wang, X., \& Jiang, Y. (2017). Improved stability of depletion heterojunction solar cells employing cation-exchange PbS quantum dots. Sol. Energy Mater. Sol. Cells 164, 122-127.

[5] Du, X., Wang, Y., Shi, R., Mao, Z., \& Yuan, Z. (2018). Effects of anion and cation doping on the thermoelectric properties of n-type PbS. J. Eur. Ceram. Soc. 38, 3512-3517.

[6] Yang, J., Zhang, X., Liu, G., Zhao, L., Liu, J., Shi, Z., Ding, J. \& Qiao, G., (2020). Multiscale structure and band configuration tuning to achieve high thermoelectric properties in n-type PbS bulks. Nano Energy 74, 104826.

[7] Kim, J., Ampadu, E. K., Oh, E., Choi, H., Ahn, H.Y., Cho, S.H., Choi, W.J., \& Byun, J.Y. (2020). Photocurrent spectra for above and below bandgap energies from photovoltaic $\mathrm{PbS}$ infrared detectors with graphene transparent electrodes. Curr. Appl. Phys. 20, 445-450.

[8] Ampadu, E. K., Kim, J., Oh, E., Lee, D. Y., \& Kim, K. S. (2020). Direct chemical synthesis of PbS on largearea CVD-graphene for high-performance photovoltaic infrared photo-detectors. Mater. Lett. 277, 128323.

[9] Zarubin, I. V., Markov, V. F., Maskaeva, L. N., Zarubina, N. V., \& Kuznetsov, M. V. (2017). Chemical sensors based on a hydrochemically deposited lead sulfide film for the determination of lead in aqueous solutions. J. Anal. Chem. 72, 327-332.

[10] Faraj, M. G. (2015). Effect of Thickness on the Structural and Electrical Properties of Spray Pyrolysed Lead Sulfide Thin Films. Am. J. Condens. Matter Phys. 5, 51-55.

[11] Cheragizade, M., Yousefi, R., Jamali-Sheini, F., Mahmoudian, M. R., Sáaedi, A., \& Ming Huang, N. (2014). Synthesis and characterization of $\mathrm{PbS}$ mesostructures as an IR detector grown by hydrogen-assisted thermal evaporation. Mater. Sci. Semicond. Process. 26, 704-709. 
[12] Mondal, A., \& Mukherjee, N. (2006). Cubic PbS thin films on TCO glass substrate by galvanic technique. Mater. Lett. 60, 2672-2674.

[13] Gozalzadeh, S., Nasirpouri, F., \& Seok, S. II (2021). Dimethylformamide-free synthesis and fabrication of lead halide perovskite solar cells from electrodeposited PbS precursor films. Chem. Eng. J. 411, 128460.

[14] Beatriceveena, T. V., Prabhu, E., Jayaraman, V., \& Gnanasekar, K. I. (2019). X-ray photoelectron and Hall studies on nanostructured thin films of PbS grown by pulsed laser deposition. Mater. Lett. 238, 324-327.

[15] Sarica, E., \& Bilgin, V. (2017). Effect of Pb:S molar ratio in precursor solution on the properties of lead sulphide thin films by ultrasonic spray pyrolysis. Mater. Sci. Semicond. Process. 71, 42-49.

[16] Kumar, K. N. C., Pasha, S. K. K., Muhammad, G. S., Chidambaram, K., \& Deshmukh, K. (2016). Influence of nickel on the structural, optical and magnetic properties of $\mathrm{PbS}$ thin films synthesized by successive ionic layer adsorption and reaction (SILAR) method. Mater. Lett. 164, 108-110.

[17] Güneri, E., Göde, F., \& Çevik, S. (2015). Influence of grain size on structural and optic properties of PbS thin films produced by SILAR method. Thin Solid Films, 589, 578-583

[18] Puišo, J., Tamulevicius, S., Laukaitis, G., Lindroos, S., Leskelä, M., \& Snitka, V. (2002). Growth of PbS thin films on silicon substrate by SILAR technique. Thin Solid Films, 403-404, 457-461.

[19] Dong, Y., Su, C., Pan, X., Zhao, Y., Wen, J., Pang, F., Huang, Y., Shang, Y., \& Wang, T. (2020). Density functional theory investigation on formation of nanoscale $\mathrm{PbS}$ materials and its fabrication in silica optical fiber via atomic layer deposition. Opt. Fiber Technol., 58, 102257.

[20] Yang, P., Song, C. F., Lü, M. K., Yin, X., Zhou, G. J., Xu, D., \& Rong Yuan, D. (2001). The luminescence of $\mathrm{PbS}$ nanoparticles embedded in sol-gel silica glass. Chem. Phys. Lett., 345, 429-434.

[21] Ketchemen, K. I. Y., Mlowe, S., Nyamen, L. D., Aboud, A. A., Akerman, M. P., Ndifon, P. T., O’Brien, P., \& Revaprasadu, N. (2018). Heterocyclic lead (II) thiourea to complexes as single-source precursors for the aerosol assisted chemical vapour deposition of $\mathrm{PbS}$ thin films. Inorganica Chim. Acta, 479, 42-48.

[22] Contreras-Rascón, J. I., Díaz-Reyes, J., Luna-Suárez, S., Carrillo-Torres, R. C., \& Sánchez-Zeferino, R. (2019). Characterisation of chemical bath deposition $\mathrm{PbS}$ nanofilms using polyethyleneimine, triethanolamine and ammonium nitrate as complexing agents. Thin Solid Films, 692, 137609

[23] Zarębska, K., \& Skompska, M. (2011). Electrodeposition of CdS from acidic aqueous thiosulfate solutionInvesitigation of the mechanism by electrochemical quartz microbalance technique. Electrochim. Acta, 56, 5731-5739.

[24] Altiokka, B., Baykul, M. C., \& Altiokka, M. R. (2013). Some physical effects of reaction rate on PbS thin films obtained by chemical bath deposition. J. Cryst. Growth, 384, 50-54.

[25] Önal, M., \& Altıkka, B. (2020a). Chemical deposition of CdS thin films in the hexagonal phase without annealing. Emerg. Mater. Res., 9, 738-742.

[26] Altıkka, B. (2015). Effects of Inhibitor on PbS Thin Films Obtained by Chemical Bath Deposition. Arab. J. Sci. Eng., 40, 2085-2093.

[27] Önal, M., \& Altıkka, B. (2020b). Pinhole-free PbS thin film production using a low-temperature chemical bath deposition method. J. Nano Res., 63, 1-9.

[28] Bhowmik, R., Murty, M. N., \& Srinadhu, E. S. (2008). Magnetic modulation in mechanical alloyed Cr1.4Fe0.6O3 oxide. PMC Phys. B, 1, 20.

[29] Altiokka, B., \& Y1ldırım, K. A. (2018). Electrodeposition of CdS Thin Films at Various pH Values, Journal of the Korean Physical Society, 72(6), 687-691.

[30] Y1ldırım, K. A., \& Altiokka, B. (2017). An investigation of effects of bath temperature on CdO films prepared by electro deposition. Appl Nanosci., 7, 513-518.

[31] Kul, M. (2019). Characterization of PbS F1lm Produced By Chemical Bath Deposition At Room Temperature. Eskişehir Tech. Univ. J. Sci. Technol. B- Theor. Sci., 7, 46-58. 